Janina Labocha

Uniwersytet Jagielloński, Kraków

janina.labocha@uj.edu.pl

\title{
PROFESOR TERESA ORŁOŚ - WYBITNA POLSKA BOHEMISTKA
}

Słowa klucze: polscy językoznawcy, bohemiści, Teresa Orłoś

Keywords: Polish linguists, Czech studies, Teresa Orłoś

Dorobek naukowy zmarłej w 2009 r. Profesor Teresy Zofii Orłoś dotyczy zarówno historii języka czeskiego i jego kontaktów z innymi językami słowiańskimi, w tym z polszczyzną, jak i współczesnych zagadnień językoznawczych, zwłaszcza z dziedziny frazeologii i słownictwa, również w ujęciu kontrastywnym do języka polskiego. Przedstawienie dokonań naukowych badaczki rozpoczniemy od nurtu historycznego, w którym mieszczą się prace naukowe traktujące o zabytkach piśmiennictwa czeskiego, ale i o słownikach, które odegrały istotną rolę w dziejach języka czeskiego i w jego odradzaniu się w XIX stuleciu. Te problemy badawcze wiążą historię języka czeskiego $\mathrm{z}$ dziejami innych języków słowiańskich, a dla polonisty są cennym uzupełnieniem dziejów polszczyzny i wkładem w tematykę czesko-polskich kontaktów językowych w przeszłości.

Dla dziejów języka czeskiego duże znaczenie miały prace badawcze T. Orłoś związane z analizą i opisem staroczeskich rękopisów z tzw. depozytu berlińskiego Biblioteki Jagiellońskiej w Krakowie oraz z Biblioteki Seminarium Duchownego w Tarnowie (Orłoś 1992: 7-40). Głębokiej analizie filologicznej i językoznawczej zostały poddane fragmenty Nowego Testamentu z XV w. z tarnowskiego seminarium oraz Ewangelia św. Mateusza z depozytu berlińskiego. Następnie badaczka omówiła inne rękopisy czeskie z tego depozytu, a mianowicie VII-wieczny czteroczęściowy rękopis, a właściwie 
razem oprawione cztery rękopisy, z których, zdaniem badaczki, na największą uwagę zasłużył pierwszy z nich Vidění a zjevení Kryštofa Kottera. Jest to pięknie zapisany i ilustrowany opis wizji i proroctw Krzysztofa Kottera, ludowego proroka, którym zainteresował się w roku 1625 Jan Amos Komenský. Obszerna przedmowa poprzedzająca rękopis z depozytu berlińskiego zawiera słowa uznania dla Kottery oraz wiarę w jego proroctwa, które dotyczyły zwycięstwa ewangelików pod wodzą czeskiego króla, Fryderyka z Palatynatu. Wiadomo, że Jan Amos Komenský osobiście przekazał Fryderykowi w roku 1626 opis wizji Kottera, jest zatem prawdopodobne, że autorem przedmowy do proroctw był sam Komenský, a oprawiony razem z trzema innymi rękopisami rękopis z depozytu berlińskiego to, jak pisze T. Orłoś, właśnie rękopis przekazany królowi. $Z$ depozytu berlińskiego pochodzi też czeski modlitewnik Prosba za milost, zawierający ponad 30 modlitw wraz ze wskazówkami, kiedy należy je odmawiać. W tekście znajdują się również formuły oraz słowa magiczne mające odżegnywać uroki i odwracać działania złych mocy, a ponadto liczne rady, co należy robić, żeby uchronić się przed złym losem. Profesor Teresa Orłoś po wnikliwej analizie zabytku datuje go na koniec XVII w.

Analizie naukowej poddała Teresa Orłoś również cenny zabytek czeskiej leksykografii, mianowicie siedmiojęzyczny słownik Piotra Lodereckera, wydany w Pradze w roku 1605. Loderecker był benedyktynem pochodzącym z Prošovic koło Pragi, a później, już po wydaniu słownika, opatem klasztoru Emaus w Pradze. Badaczka wcześniej analizowała słownictwo zawarte w pięciotomowym słowniku czesko-niemieckim Józefa Jungmanna, koncentrując swoją uwagę na licznie występujących w słowniku polonizmach. Do tego zagadnienia powrócimy w związku z pracami Profesor Teresy Orłoś o czesko-polskich kontaktach w dziejach obydwu języków. Wróćmy zatem do słownika Lodereckera, który powstał jako uzupełnienie o część czeską i polską wydanego w 1595 r. przez Fausta Vrančicia z Szibenika pięciojęzycznego słownika łacińsko-włosko-niemiecko-dalmatyńsko-węgierskiego. Teresa Orłoś podaje, że w roku 1966 Vilem Frančić wygłosił w Komisji Językoznawstwa PAN w Krakowie referat o części polskiej słownika Lodereckera, która, jego zdaniem, zawiera 436o haseł jako odpowiedników 5077 haseł łacińskich. Część czeska, według obliczeń badaczki, zawiera 4412 haseł. Przypuszcza się, że Loderecker przy pisaniu czeskiej i polskiej części słownika korzystał z dostępnych za jego czasów słowników łacińsko-czeskich i łacińsko-polskich, ale wysuwane są też hipotezy, że przy opracowaniu działu polskiego pomagał mu Bartłomiej Paprocki. Zdaniem Frančicia słownictwo polskie u Lodereckera wykazuje największą zgodność z materiałem zawartym w polsko-łacińskim słowniku Jana Mączyńskiego, wydanym w roku 1564. Teresa Orłoś obliczyła, że dział polski w słowniku Lodereckera zawiera około 100 bohemizmów. Oprócz tych, które były już wówczas zadomowione w polszczyźnie, pojawiają się również, wprowadzone przez Lodereckera, nowe, będące spolszczeniami wyrazów czeskich. Na temat słownika Lodereckera Profesor Teresa Orłoś napisała kilka artykułów, przedrukowanych w tomie Studia bohemistyczne I (1992: 41-72). Jeden z nich poświęcony został 
bohemizmom w polskim dziale słownika Lodereckera (1992a: 57-65). Stanowią one 3\% haseł działu polskiego i można je podzielić na bohemizmy gramatyczne, leksykalne i znaczeniowe. Szczególnie dokładnie zostały omówione bohemizmy fonetyczne i słowotwórcze. Te ostatnie reprezentuje np. wyraz ławiczka, w którym w miejsce polskiego sufiksu deminutywnego -eczka, wprowadzono czeski -iczka. Obok formy przymiotnika $d z i k i$ pojawia się też postać przejęta z czeskiego, mianowicie $d z i w o k i$ (por. czes. divoký). Spośród mniej znanych bohemizmów leksykalnych T. Orłoś wymienia np. wyrażenie chłupki na brodzie w znaczeniu 'zarost' (z czeskiego chloupky). Zwraca też uwagę na to, że wyraz chłupy występuje w gwarach Śląska Cieszyńskiego, podobnie jak przymiotnik chlupaty, notowany zresztą w słowniku Lindego. Do innych mniej znanych bohemizmów należą wyrazy: cztenarz 'czytelnik', polsztarz 'poduszka', przekażka 'przeszkoda', nebo 'albo' i inne.

W swoim dorobku dotyczącym historii języka Profesor Teresa Orłoś wiele uwagi poświęciła polonizmom w języku czeskim. W roku 1967 opublikowała książkę Zapożyczenia polskie $w$ słowniku Jungmanna, zaś w roku 1987 - Polonizmy w czeskim języku literackim. Szerzej, bo nie tylko o polskich, ale i innych zapożyczeniach, pisała w książce opublikowanej w roku 1972 Zapożyczenia słowiańskie w czeskiej terminologii botanicznej i zoologicznej. Problematyce tej poświęciła uwagę również w wielu artykułach. Zapożyczanie z innych języków słowiańskich stało się w okresie czeskiego odrodzenia narodowego pilną potrzebą, ponieważ język czeski znajdował się w stanie upadku. Ustalaniem od nowa norm gramatycznych odradzającej się w XIX w. czeszczyzny zajął się wybitny czeski uczony z pierwszej generacji czeskiego odrodzenia narodowego, Józef Dobrovský, natomiast stworzenie pełnego zasobu leksykalnego języka czeskiego stało się celem działalności przedstawiciela drugiej generacji tzw. budzicieli narodowych, mianowicie Józefa Jungmanna, autora pięciotomowego słownika języka czeskiego, wzorowanego na słowniku języka polskiego Samuela Bogumiła Lindego. Słownik Jungmanna ukazał się drukiem w latach 1834-1839. Jak pisze Teresa Orłoś, największy i najtrwalszy wpływ słownika Lindego przejawił się w ogromnej liczbie zapożyczeń z języka polskiego. Oprócz języka polskiego źródłem zapożyczeń w słowniku Jungmanna były też inne języki słowiańskie: rosyjski, serbo-chorwacki, słoweński. W książce Polonizmy w czeskim języku literackim Teresa Orłoś sporządziła wykaz polonizmów w języku czeskim, zaznaczając jednak, że w niektórych wypadkach można mówić tylko o wyrazach podejrzanych o polskie pochodzenie. Wykaz liczy 2190 pozycji, z czego 1640 to wyrazy niespecjalistyczne, reszta zaś (550) - terminy naukowe. Dalej stwierdza, że spośród tych 1640 wyrazów około 370 było używanych przez jakiś czas (22\%), a 400 wyrazów, czyli około $25 \%$, zachowało się do dnia dzisiejszego. Dodaje, że 170 (czyli 10,5\%) należy do słownictwa o znacznej częstości użycia, ponieważ są notowane w czeskim słowniku frekwencyjnym uwzględniającym 10 tysięcy najczęściej używanych wyrazów. Z 550 polonizmów z zakresu nazewnictwa naukowego dotrwało do dziś ponad 200, czyli około $37 \%$. Przeważa wśród nich słownictwo przyrodnicze. Łącznie z 2190 wyrazów uważanych za polonizmy do dziś 
utrzymało się ponad 600 wyrazów, czyli mniej niż 30\%. Do najstarszych polonizmów w języku czeskim można zaliczyć nazwy botaniczne, np. rdest, vitečky notowane już w XVI w., modřín w XVIII w., cvikla, gatě, táčky, výměr zapisane w tekstach Komenskiego. Jak podkreśla T. Orłoś, większość zapożyczeń polskich w języku czeskim pochodzi z pierwszej połowy XIX w. Z drugiej połowy XIX i początku XX w. pochodzą takie polonizmy, jak np: bař̌č, folvark, goral, hulanka, krochmal, lidový, lura, Moskal, pšakrev, sešit, šelest, valčík i in. Stosunkowo dużo zapożyczeń z języka polskiego zawiera książka Antala Staška Blouznivci našich hor wydana w roku 1895. $\mathrm{Z}$ nowych zapożyczeń polskich, jakie pojawiają się w tym tekście, można wymienić np.: žitňovka, buntovník, herbata. W wykazie sporządzonym przez T. Orłoś w książce Polonizmy w czeskim języku literackim szczególne znaczenie mają te wyrazy o znacznej frekwencji w języku czeskim. Są to np. wyrazy: lidový, věda, vzájemnost, vzájemný, navzájem, zdroj, otvor. Wyraz výspa w takim znaczeniu, jakie ma w polszczyźnie, jest w języku czeskim archaizmem, Używa się tu wyrazu ostrov. Nadal jednak wyraz výspa pojawia się w znaczeniu przenośnym, np. öeská výspa v německém moři.

O wzajemnych stosunkach czesko-polskich pisała również Profesor Teresa Orłoś w książce Tysiąc lat czesko-polskich związków językowych, wydanej w roku 1993 w wersji polskiej i czeskiej. Książka ta poszerza znacznie opracowanie pt. Polsko-czeskie związki językowe, wydane w roku $1980 \mathrm{ow}$ serii Nauka dla wszystkich. W rozdziale pierwszym autorka omawia wspólne pochodzenie obydwu języków. Warto tu dodać, że praca magisterska Teresy Orłoś, pisana pod opieką naukową Tadeusza Lehra-Spławińskiego, nosząca tytuł Element prasłowiański w dzisiejszym słownictwie czeskim, została opublikowana w roku 1958 w „Studiach z Filologii Polskiej i Słowiańskiej”. T. Orłoś pokazuje początki różnicowania się języków czeskiego i polskiego, chwilową utratę łączności czeskiego i słowackiego z zespołem zachodniosłowiańskim spowodowaną tym, że jakiś czas po przejściu Karpat przez Słowian południowych (około $\mathrm{V}$ w.) również plemiona czeskie i słowackie przekroczyły Sudety i zachodnie Karpaty, czego skutkiem jest wspólny rozwój z odłamem południowosłowiańskim prasłowiańskich grup TorT, TolT w TraT, TlaT, por.: czes. hlava, zlato, kráva, hrad wobec polskich form: głowa, złoto, krowa, gród. Przodkowie Czechów i Słowaków zachowali również tzw. sonanty, czyli dawne zgłoskotwórcze $r, l$, podobnie jak Słowianie południowi. W pozostałych językach słowiańskich, w tym w języku polskim, wprowadzono przed $r, l$ element samogłoskowy, por. czes. krk, vrch, vlk, plný z polskimi odpowiednikami kark, wierzch, wilk, pełny. Łączność językową przodków Czechów i Słowaków ze Słowianami południowym przerwał w VI i VII w. najazd Awarów. W IX w. ludy czeskie i słowackie zostały definitywnie oddzielone od Słowian południowych przez Madziarów. Po zerwaniu kontaktów ze Słowianami południowymi przodkowie Czechów i Słowaków nawiązali ponownie łączność z pozostałymi plemionami zachodniosłowiańskimi, co znalazło odbicie w dalszym rozwoju językowym. Teresa Orłoś zwraca również uwagę na podobieństwa w zakresie słownictwa odziedziczonego z epoki prasłowiańskiej. Jak pisze badaczka, w języku polskim zachowało się bez zasadniczych zmian 1700 
wyrazów odziedziczonych z prasłowiańszczyzny, zaś w języku czeskim jest ich około 2000. 124 wyrazy zachowane w czeszczyźnie nie mają swoich odpowiedników w polskim języku literackim. Są to np. wyrazy játra 'wątroba', sever 'północ', skvrna 'plama'. Z kolei 112 wyrazów polskich pochodzenia prasłowiańskiego nie ma ekwiwalentów w czeszczyźnie literackiej, por. bocian - czes. čáp, tęcza - czes. duha, smok - czes. drak. Niektóre z tych wyrazów zachowały się jednak w gwarach polskich czy też czeskich. Choć podstawowy zrąb słownictwa czeskiego i polskiego, stanowiący najstarszą warstwę, jest wspólny, to jednak oba języki wykazują dość istotne różnice leksykalne, które wynikają z odmiennego rozwoju słowotwórczego, a także z faktu, że nie zawsze oba języki zapożyczały z tych samych źródeł. I tak na przykład język niemiecki był źródłem wielu wyrazów przejętych przez język czeski, ale niewprowadzonych do polszczyzny, por. np. czeski wyraz nudle 'makaron, kluski'. W mniejszym stopniu niż język polski ulegała czeszczyzna wpływom francuskim. Widać to wyraźnie we frazeologii, która w języku czeskim była pod silnym wpływem niemieckim, por. np. czeskie wyrażenie velké zvíre z niem. grosses Tier, którego polskim odpowiednikiem jest frazeologizm gruba ryba.

O wpływach języka czeskiego na rozwój polszczyzny literackiej traktuje drugi rozdział omawianej książki Profesor Teresy Orłoś. Pisze w nim autorka o zapożyczeniach terminologii chrześcijańskiej za pośrednictwem języka czeskiego, który bezpośrednio czerpał z zasobu terminów grecko-łacińskich (np. pacierz, diabeł, apostoł), częściowo także staro-cerkiewno-słowiańskich (np. cerkiew, błogosławić, Bogurodzica, prorok) lub przyjmował pośrednictwo bawarskie (np. kościót, ołtarz, chrzest), niekiedy też romańskie (np. krzyż, Rzym). Polszczyzna zapożyczała też czeskie kalki językowe (np. czyściec, małżonka), czeskie neologizmy (np. gromnica, kazanie) oraz neosemantyzmy (np. bóg pierw. 'szczęście, bogactwo', niebo pierw. 'chmury, obłoki', piekło pierw. 'smoła', święty pierw. 'silny, mocny'). Wpływy czeskie na piśmiennictwo polskie nie dotyczą jeszcze $\mathrm{Ka}$ zań świętokrzyskich oraz Kazań gnieźnieńskich, gdzie pojawiają się tylko te zapożyczenia, które należą do najstarszej warstwy, przejętej jeszcze w okresie chrystianizacji. Dopiero kolejne polskie zabytki piśmiennicze, tj. Psałterz floriański, Psałterz puławski, Biblia królowej Zofii, wykazują zależność językową od przekładów czeskich. Polsko-czeskie związki rozwinęły się w XIV i XV w. dzięki oddziaływaniu nie tylko na piśmiennictwo, ale również na organizację nauki. W tej dziedzinie główną rolę odegrał Uniwersytet Karola w Pradze, założony w roku 1348, będący z jednej strony miejscem kształcenia Polaków, z drugiej wzorcem dla organizatorów i wykładowców krakowskiego Studium generale, które powstało w roku 1364, jeszcze bez wydziału teologicznego. Ten ostatni udało się otworzyć w roku 1397 dzięki staraniom królowej Jadwigi i zgodzie papieża Bonifacego IX, w rezultacie czego Akademia Krakowska stała się placówką o znaczeniu europejskim. W czasach panowania Jadwigi i Jagiełły czeszczyzna pełniła funkcję języka dworskiego, a biblioteka królowej zawierała więcej ksiąg czeskich niż polskich. W okresie ruchu husyckiego w Czechach polszczyzna przejęła kilka czeskich terminów wojskowych, np. tabor, rusznica, hakownica, puszka 'strzelba', porucznik, hetman, hasto. W XVI w. wpływ czeski 
ogarnął już nie tylko polszczyznę pisaną, ale także język mówiony. Jak pisze T. Orłoś, znajomość czeszczyzny uważana była za znamię przynależności do warstw elitarnych. Do dobrego tonu należało wtrącanie do rozmowy wyrazów czeskich, co między innymi wyśmiewał Łukasz Górnicki w Dworzaninie polskim, mówiąc, że Polak

Chocia nie będzie w Czechach, jedno iż granicę śląską przejdzie, to już inaczej nie będzie chciał mówić jedno po czesku, a czeszczyzna, wie to Bóg, jaka będzie. A jeśli mu rzeczesz, żeby swoim językiem mówił, to powieda, iż zapomniał, abo ze mu się przyrodzony język prawdziwie gruby widzi [...] (za: Orłoś 1993: 25).

Od czechizmów roiły się, jak pisze T. Orłoś, niektóre teksty polskich innowierców, np. Jana Sandeckiego-Maleckiego, którego mocno krytykował inny pisarz protestancki, Jan Seklucjan, sugerując, że język jego tekstów jest zepsutą czeszczyzną. Zwolennikiem stosowania licznych czechizmów w tekstach polskich przekładów był też syn Jana, Hieronim Sandecki-Malecki, który w przedmowie do wydanej w roku 1574 Postylli domowej wyraził pogląd, że czeszczyzna i polszczyzna stanowią jedynie dialekty jednego języka. Pisząc o sztuce tłumaczenia, stawiał za wzór język czeski, podkreślając, że każdy tłumacz powinien go dobrze opanować. Wpływy czeskie słabną w II połowie XVI w. i ustają prawie zupełnie w wieku XVII. Do wyrazów pochodzenia czeskiego używanych w polszczyźnie po dziś dzień należą np.: straż, własność, zwłaszcza, brama, błahy, hańba, wesele, obywatel, Władysław, szata, kuleć. Nie licząc derywatów, liczbę zapożyczeń czeskich w języku polskim szacuje się na około 1600.

W roku 1571 została wydana Gramatyka czeska Jana Blahoslava, biskupa braci czeskich. Opisując dialekty czeskie, morawskie i śląskie, autor poświęcał uwagę językom słowiańskim, które dość zabawnie, zdaniem Teresy Orłoś, charakteryzował. Pisał, że „první a nejpřednější dyalectus je řeč česká [...]”. W polszczyźnie nie podobało mu się „nepěkné skrze nos mluvení: nebo Poláci jakýms nám nepř́iemným huhňáním velmi sobě svůj hovor kazí”. Równocześnie Blahoslav wyrażał podziw dla rozkwitu literatury polskiej w XVI w., a o języku polskim stwierdzał, że nie trzeba go opisywać, bo jest znany w Czechach (Orłoś 1993: 28-29).

Rozdział trzeci książki Tysiąc lat czesko-polskich związków językowych pokazuje oddziaływanie polskie na odradzający się czeski język literacki. Wcześniej była już mowa o słowniku Jungmanna i jego działalności na rzecz odnowienia języka czeskiego tak, by mógł pełnić wszystkie funkcje, w tym poetyckie i naukowe. T. Orłoś podaje, że Jungmann był rektorem Uniwersytetu Karola w Pradze, a także członkiem Warszawskiego Towarzystwa Przyjaciół Nauk (od 1827 r.) oraz Krakowskiego Towarzystwa Naukowego (od 183 r.). Józef Jungmann dążył do odrodzenia języka czeskiego w dwojaki sposób: po pierwsze, przyswajając Czechom wybitne dzieła literatury światowej, po drugie - gromadząc materiał do wielkiego słownika narodowego. Sam był autorem utworów poetyckich, głównie jednak kładł nacisk na działalność translatorską, gdzie szczególnie mocno ujawniły się wpływy polskie, ponieważ Jungmann posługiwał się istniejącymi już przekładami polskimi. 
Drugi nurt badań Profesor Teresy Orłoś obejmuje zagadnienia współczesnego języka czeskiego, zwłaszcza w jego kontaktach z językiem polskim i innymi językami słowiańskimi. W roku 1996 ukazał się Czesko-polski słownik skrzydlatych słów, do którego indeks znaczeniowy opracowała Joanna Hornik. Następnie wraz z zespołem współpracowników Teresa Orłoś opracowała i zredagowała Czesko-polski słownik zdradliwych wyrazów i pułapek frazeologicznych, wydany w roku 2003. Rok później ukazała się kolejna książka, rezultat pracy zespołowej prowadzonej pod kierownictwem i z inicjatywy Teresy Orłoś, praca bardzo ważna dla czesko-polskich badań kontrastywnych pt. Czesko-polska pozorna ekwiwalencja jezzkowa. Materiały pomocnicze dla studentów, polskich bohemistów i czeskich polonistów. W roku 2009, niestety już po śmierci Profesor Teresy Orłoś, ukazał się Wielki czesko-polski słownik frazeologiczny, który zawiera około pięciu tysięcy artykułów hasłowych. Został opracowany przez zespół językoznawców pod kierownictwem T. Orłoś i oparty na jej koncepcji naukowej. Słownik poprzedziła wydana w roku 2005 książka autorstwa T. Orłoś pt. Studia z frazeologii czeskiej i polskiej.

Omówienie bogatego dorobku T. Orłoś z dziedziny frazeologii, leksykologii i leksykografii oraz innych jej prac poświęconych współczesnym problemom języka czeskiego, a także jego aspektom porównawczym w stosunku do polszczyzny i innych języków słowiańskich zajęłoby dużo miejsca i czasu, skupię się zatem na przedstawieniu tylko wybranych przykładów ilustrujących tę tematykę badawczą. Zacznijmy od pokazania polsko-czeskich różnic frazeologicznych na kilku przykładach: Polskiemu frazeologizmowi kupować kota w worku odpowiada czeski kupovat zajíce v pytli. Czeskim odpowiednikiem zwrotu polskiego zaleźć komuś za skórę jest zalézt někomu za nehty, czyli za paznokcie. Po polsku mówimy wisieć na włosku po czesku víset na nitce. Polskiemu wyrażeniu osioł patentowany odpowiada czeskie korunovaný vůl.

Do czesko-polskich zdradliwych słów możemy z kolei zaliczyć czeski rzeczownik hroch, którego znaczenie daleko odbiega od tego, co znaczy polski wyraz groch. Czeski hroch to bowiem polski hipopotam. Czeska kapusta to ekwiwalent polskiego zestawienia włoska kapusta, a zwykła kapusta nazywa się po czesku zelí. Czeskiemu wyrazowi kreslo odpowiada polski fotel, zaś polskie krzesło to po czesku židle. Różnice w zakresie odmiany wyrazów brzmiących podobnie w obu językach można zilustrować następująco: dam coś angliście, staroście, hokeiście - dám něco anglistovi, starostovi, hokejistovi; to sa biskupi, gospodarze, koledzy, kucharze - to jsou biskupové, hospodári, kolegové, kuchaři.

Do czesko-polskiej pozornej ekwiwalencji należy również zaliczyć zdradliwą odpowiedniość rodzajową. Teresa Orłoś podaje, że w ponad 430 czesko-polskich parach wyrazowych różniących się rodzajem gramatycznym przeważają wyrazy obcego pochodzenia. Porównajmy kilka wybranych przykładów: ta adresa, banka, universita, rýže, etapa, garáž, stáž - ten adres, bank, uniwersytet, ryż, etap, garaż, staż; ten benzin, citron, vitamin, recept, salát - ta benzyna, cytryna, witamina, recepta, sałata; ten archiv, bílek, honorár̆, seminár - to archiwum, białko, honorarium, seminarium. 
Profesor Teresa Orłoś pisała również o współczesnych polsko-czeskich związkach i stereotypach narodowych. Na uwagę zasługuje tu zwłaszcza artykuł opublikowany w „Języku Polskim” w 1996 r. Wzajemne polskie i czeskie oceny oraz stereotypy narodowościowe i językowe. Temu zagadnieniu poświęciła też końcową część artykułu Wzajemne wplywy językowe czesko-polskie i ich uwarunkowania historyczne, opublikowanego w roku $1997 \mathrm{w}$ tomie Konsekwencje sasiedztwa polsko-czeskiego dla rozwoju języka i literatury. Pisze tam, że zarówno Czesi, jak i Polacy są zdania, że język sąsiada jest zabawny, a nawet śmieszny. Dlatego też przed bohemistami polskimi i polonistami czeskimi stoi ważne zadanie - dążenie do poprawy wzajemnych stereotypów narodowych przez szerzenie wiedzy o wspólnych związkach językowych i kulturalnych w przeszłości.

Wszyscy, którzy znali bliżej Profesor Teresę Orłoś - jej uczniowie, współpracownicy, koledzy i przyjaciele, wiedzą, że śledzenie i opis historycznych związków językowych czesko-polskich i polsko-czeskich Uczona uważała za swoją misję, rodzaj obowiązku, ale miłego sercu, bo przecież w Pradze, gdzie spędziła szereg lat, gdzie ukończyła szkołę średnią, gdzie zdała maturę, gdzie miała krewnych i przyjaciół, w Pradze właśnie zrodziła się w niej potrzeba i chęć zrozumienia, z czego wynikają i na czym polegają czesko-polskie i polsko-czeskie podobieństwa, ale także, i to nawet bardziej, różnice zarówno w mentalności ludzi, jak również w ich języku. Temu zadaniu poświęciła całe swoje życie, a różnorodny i bogaty dorobek naukowy stawia Profesor Teresę Orłoś w gronie wybitnych polskich i czeskich bohemistów oraz badaczy czesko-polskich i polsko-czeskich kontaktów językowych.

\section{Literatura}

OrŁoś T., 1958, Element prasłowiański w dzisiejszym stownictwie czeskim, „Studia z Filologii Polskiej i Słowiańskiej" 3, s. 267-283.

OrŁoś T., 1967, Zapożyczenia polskie w słowniku Jungmanna, Kraków.

OrŁoś T., 1972, Zapożyczenia słowiańskie w czeskiej terminologii botanicznej i zoologicznej, Kraków.

ORŁoś T., 1980, Polsko-czeskie związki językowe, „Nauka dla Wszystkich” nr 324, Wrocław. Or£oś T., 1987, Polonizmy w czeskim języku literackim, Kraków.

Or£oś T., 1992, Studia bohemistyczne, cz. I-II, Kraków.

OrŁoś T., 1993, Tysiąc lat czesko-polskich związków językowych, Kraków.

OrŁoś T., 1996, Wzajemne polskie i czeskie oceny oraz stereotypy narodowościowe i językowe. Przeszłość - teraźniejszość, „Język Polski” LXXVI, s. 1-10.

OrŁoś T., 1997, Wzajemne wplywy jezzkowe czesko-polskie i ich uwarunkowania historyczne, [w:] T. Orłoś, J. Damborský (red.), Konsekwencje sasiedztwa polsko-czeskiego dla rozwoju jezzka i literatury, Wrocław, s. 9-21.

Or£oś T. (red.), 2003, Czesko-polski słownik zdradliwych wyrazów i pułapek frazeologicznych, Kraków. 
OrŁoś T. (red.), 2004, Czesko-polska pozorna ekwiwalencja językowa. Materiały pomocnicze dla studentów, polskich bohemistów i czeskich polonistów, Kraków.

OrŁoś T., 2005, Studia z frazeologii czeskiej i polskiej, Kraków.

OrŁoś T. (red.), 2009, Wielki czesko-polski słownik frazeologiczny, Kraków.

OrŁoś T., Hornik J., 1996, Czesko-polski słownik skrzydlatych słów, Kraków.

\section{Professor Teresa Orłoś - an outstanding Polish bohemist Summary}

Professor Teresa Orłoś, an outstanding Polish bohemist, has authored numerous works on the history of the Czech language, and historical and contemporary lexicology and lexicography. Beside linguistic problems in Czech philology, she has strongly emphasized the need of study and the characteristic of mutual Czech-Polish and Polish-Czech contacts. She has demonstrated the Czech influence on mediaeval and $16^{\text {th }} \mathrm{c}$. Polish, but also the importance of Polish for the Czech language when it was recovering in the $19^{\text {th }} \mathrm{c}$. from a serious decline. Professor Orłoś passed away in 2009. The contemporary part of her research is mainly represented by her phraseological works and rich lexicographic activities, conducted together with the linguistic team she led. 